\title{
Peace Education in Islamic Da'wah Through Comic
}

\author{
Laily Fitriani ${ }^{1, *}$ \\ ${ }^{1}$ UIN Maulana Malik Ibrahim Malang, Indonesia \\ "Corresponding author.Email: laily@bsa.uin-malang.ac.id
}

\begin{abstract}
Peace education can be applied to the younger generation through curriculum and peace culture movements in schools. In its development, practicing peace education is not easy. One of the Islamic da'wah media that is quite interesting for the younger generation is comics. Comics are interesting works for children and teenagers. Through this visual media, comics come with various themes, one of which is the theme of Islamic da'wah. Comics have their characteristics by providing values in the form of text and images as a medium to internalize the values contained in comics. This study describes 1) the role of comics in peace education; 2) the values of peace education in the Iqomic Da'wah ala Komikus Comic. This paper is based on the data contained in the Iqomic Da'wah ala Komikus comic which was collected through content analysis which was determined based on the criteria. Data was analyzed qualitatively according to Miles and Huberman. The results of this study are: 1) the media has a role in the spread of Islamic da'wah, including visual media, namely comics; 2) four values of peace education appear in this Iqomic Da'wah ala Komikus comic, namely not accusing people/groups, having to believe if the truth comes from Allah, not joking in the Shari'a, and 3) not having bad things to others.
\end{abstract}

Keywords: Peace education, Islamic Da'wah, Comic

\section{INTRODUCTION}

Building peace in society is not easy. Society as a community will give birth to various problems that occur in society. Conflicts can be created from various misunderstandings, especially in understanding religious texts. One of the efforts in forming a culture of peace in children is through peace education. This education can enter through the religious culture of the school, the school curriculum, to the interaction between one student and another. So that, from education whose individual development and intellectual production will be expanded into social development of an active society to maintain peace [1] Peace education should be given since children because children can do imitations, as well as through the qudwah hasanah of the people around them.

Efforts to bring about peace and preaching about the morals of Muslims and Muslimah in the community take various forms. Islamic da'wah today must be following the needs of the community [2] One of them is through comics media that are suitable for use by children and teenagers, even though comics are also interesting reading for adults. Comic media has also been carried out in Islamic religious learning in schools which has been proven to increase students' motivation and learning outcomes in learning Islamic education learning outcomes [3], [4].
Da'wah is highly recommended by Allah SWT, as explained in the Bukhari hadith "Say even one verse ..." This hadith recommends that every Muslim always preach in any case, giving goodness to others even though it is a verse / few / according to his ability.

Da'wah, sometimes synonymous with old people. However, children, adolescents, and adults are also targets for continuing to call for goodness. One model of da'wah for children and adolescents is to use media, visual and non-visual, such as storybooks, comics, and films. This means that da'wah does not have a heavy orientation and seems rigid, but preaching to children through this media can create an image that Islamic teachings are not rigid, Islamic teachings that are internalized in daily life will have a positive influence on children's religious life. Therefore, it is necessary to socialize child-friendly media in preaching.

Comics are an alternative to preaching in the modern era. From the comics, the message of da'wah will be obtained as research has been carried out by [5] where communication will be conveyed properly through symbols and writings conveyed in comics. The comic Iqomik Da'wah ala Komikus was born in the context of preaching and spreading Islamic values through visual and print media. It is hoped that with this comic media, Islamic da'wah does not seem rigid, 
but raises awareness to study Islam more deeply through daily activities. This paper will discuss the role of comics on Islamic da'wah to children and the values of peace education in Iqomik Da'wah ala Komikus comic.

\section{LITERATURE REVIEW}

\subsection{Peace Education}

Peace education is one of the educations that should exist and be developed in families, schools, and communities. This is because peace education aims to equip citizens with knowledge, attitudes, and skills on how to establish peace in society, as stated by [6] Education has become a tool for the world to transform generations. Since 1945, UNESCO has been working through education to promote international peace and the general welfare of mankind, including by improving the curriculum and teacher training [7]. Building peace education must be trained in children from an early age by illustrating how they can interact with others without conflict. Through peace education that is built from an early age, it will give birth to a generation that is minimal in the conflict in understanding the harmonization of life and also in understanding religious literacy, because [8] the seeds of religious radicalism do not always appear is due to religious understanding, but there are differences in religious views that arise and are present in society. According to [9] one way to build peaceful education is to educate the next generation. Therefore, peace education can be created by strengthening social relations between individuals, families, and communities, to be able to provide a peaceful space and understand the differences that occur.

\subsection{Islamic Da'wah}

The main purpose of da'wah is to convey (tabligh) treatises or divine messages using both written and spoken words. With humans as the target object. [10] Islamic da'wah in this era of globalization has many new challenges. Globalization is synonymous with changes in all fields, including technology. This developing technology also causes the media to develop as well. The challenge of da'wah with the role of the media is getting bigger. So that the field of da'wah is getting more difficult, where jihad in the field of da'wah struggles so that information is not controlled by the owner of the information [11]. To get a proper understanding of da'wah, it is necessary to have an Islamic da'wah strategy that is based on the proselytizing of da'wah to the community [12]. Islamic da'wah today is not only intended for the older generation but the younger generation, even children. Through comic media, messages of morality, creed, and sharia as conveyed by [13] will be conveyed by providing interesting illustrations, so that comics indirectly make a positive contribution in developing da'wah strategies and planting peace education. Therefore da'wah through print media is one of the media for spreading ideas for change, enlightenment, Islamic enthusiasm, and Islamic optimism [14] and also a medium that still exists and is packaged attractively in its delivery, one of which is through comics.

\subsection{Comic}

Comics are a medium used to express ideas with images, often in combination with text or other visual information. Iqomic Da'wah Ala Komikus is a medium in the form of writing and images containing invitations in the form of promotion and Islamic da'wah of good values exemplified by the Prophet. Iqomic Da'wah ala Komikus has become an alternative to Islamic da'wah to the younger generation.

This Iqomic Da'wah ala Komikus is one of the comics that contain the da'wah of Islam. Written by 22 comic artists and edited with Woro Lestari. This Comic was published by Salsabila Publisher in east Jakarta in 2018.

\section{METHOD}

This research is descriptive qualitative research by content analysis approach. This method describes the role and values in Iqomik Da'wah Ala Komikus. The primary data is in the form of a comic book entitled Iqomic Da'wah ala Komikus. Secondary data is in the form of information that supports primary data, namely in the form of journals and other documents. Data collection techniques in the form of using reading the Iqomic Da'wah Ala Komikus to classified and note-taking techniques to describe the role and values in Iqomic Da'wah Ala Komikus and data analysis through descriptive analysis by using Miles and Huberman by data reduction, data presentation, and conclusion.

\section{RESULT}

\subsection{The Role of Comic of Peace Education in Children}

Comics as a media for children's and youth's literacy are media that we cannot underestimate. The development of the comic world is quite significant. In the era of the 2000s, the emergence of various genres in the world of literacy which led to the publication of various literary works became one of the important 
milestones in the development of modern literature in Indonesia, including the emergence of comics. Comics as light reading are still in demand by children, teenagers, and adults. Along with the development of time, comics are not only synonymous with funny stories that contain laughter, but comics have now become a medium for preaching.

The comic faces of children, teenagers, and adults not only tell about daily life how Muslims behave but also tell about history, Islamic civilization, Islamic figures, and hadith morals. So that there are efforts made by comic artists in preaching through comics, namely trying to build awareness of readers to know the values that are present in Islamic da'wah comics, practice them and internalize them in their readers.

Thus, Islamic da'wah is now easier to use as comics media, so the values of da'wah will be absorbed easily.

\subsection{Peace Education Values in Islamic Da'wah Comic}

Technological advances have become a space for anyone to create, including comic artists. One of the interesting and popular works that are still in demand is comics. Comics are one of the media that are still favored by children and teenagers. Through comics, comic artists provide goals, values, and characters that can more or less affect the lives of children and adolescents. As light reading material for children and adolescents, comics appear with concise titles, contain broad meanings, are drawn with interesting strokes, and can tell the overall content of the theme through the stories raised.

Each comic has a value and purpose that is depicted through several scenes or narratives in the comic, as contained in Iqomic Da'wahh ala Komikus. Iqomic Da'wahh a la Komikus was written by 22 different comic artists with the central theme of how Muslim morals are towards themselves and others.

In the comic Iqomic Da'wahh ala Komikus, it consists of 22 themes with the values in the comic content there are several values of reconciliation education, namely:

1. Should not accuse people/groups carelessly in the title Ketika Shalat Jumat tanpa Khutbah (When Friday prayers without a sermon.).

"Tidak ada khutbah saat salat Jumat, apakah tidak sah, kan hari Jumat?"

"Atau mungkinkah.. Ini ajaran baru, sekte baru, sekte baru, bukan? Ini harus dilaporkan ke Kementerian Agama." (Lestari, 2018: 7-10).

(There is no sermon during the Friday prayer, is it not valid, is it Friday?"
"Or could it be.. This is a new teaching, a new sect, a cult, isn't it? This must be reported to the Ministry of Religion).

The scene in this comic depicts an angry man accusing the mosque used as a place of prayer as belonging to a certain sect because Friday prayers are without a sermon, in which the man falls asleep during Friday prayers, so he wakes up when Friday prayers are about to begin. Then the arrival of the Imam of the mosque clears the situation.

2. Must believe in the truth if the truth comes from Allah and His Messenger in the title Cover Aurat (Now Age).

"Muslimah baru hijrah? Good. Sudah terdorong untuk menutup aurat itu sudah baik. Lebih baik kalau mau mendalami ilmu agamamu, biar semakin baik menutup auratnya juga akhlaknya". (Lestari, 2018: 41).

"Muslimah... New to Hijrah? Good. It's good if you want to cover your aurat. It's even better if you want to explore your religious knowledge. Let it be better to cover his aurat, as well as his morals."

The scene depicts a Muslim woman covering her aurat. The message in this comic emphasizes the importance of covering aurat for women today, then shows how Muslim women should cover their genitals.

3. Not joking in the Shari'a in the title "Lho Baru Tau?" "Wah, ada ninja, eh bukan, manusia dalam karung."

"Celana cingkrang, rumahnya habis kebanjiran, ya?" (Lestari, 2018: 59).

"Wow, there's a ninja sh, not a human in a sack"

"Cingkrang pants, the house is flooded huh?"

These two dialogues show that it is not permissible to joke in matters of Allah's Shari'a. The existence of this image is still a problem among the community.

4. Do not have bad morals, such as envy and envy in the title The Safe (Slice of Advice)

"Cih, paling si Bagus sedekah Cuma pencitraan".

"Wah, Pak RT beli mobil baru pasti hasil korupsi".

"Cuma lomba gitu doang, gua juga bisa". (Lestari, 2018: 207).

"At least the good one is just an image"

"Wow... Mr. RT bought a new car, it must be the result of corruption."

"What's so great? It's just a competition like that, I can also do it"

The dialogue above illustrates that there are people who find it difficult to see the happiness of others. Therefore, a Muslim tries to improve his morals, because keeping the heart from envy is not easy.

\section{DISCUSSION}

Building peace has become a fairly loud discourse. Along with the emergence of various religious conflicts in society, peace is expected to be able to be 
practiced in the religious life of the Indonesian people, including children. One of the efforts to build peace in children through literary works in comics.

Comics are works of interest to children and teenagers. Through this visual media, comics come with various themes, one of which is the theme of Islamic da'wah. This comic media can also be used as teaching material in several subjects such as mathematics which results in that this comic is practical to use and can achieve the implementation of the subject [15] The concept of Islamic da'wah through this comic makes it easier for children and teenagers to be able to practice good morals that are being carried out in daily life so that the values of Islamic da'wah can be internalized in each individual.

The integration of Islamic da'wah values in this comic can be integrated directly, through the media of images and words expressed. As stated by [16] that direct integration in peace education is effective in understanding peace. This research contributes something new where the use of comics media as a visual media in Islamic da'wah is easily accessible to children and teenagers.

\section{CONCLUSION}

Comics are interesting works for children and teenagers. Through this visual media, comics come with various themes, one of which is the theme of Islamic da'wah. Comics have their characteristics by providing values in the form of text and images as a medium to internalize the peace education values contained in the comic content.

This study strengthens previous research related to the role of print media in the development of Islamic da'wah strategies to the younger generation, especially children. The results of this study provide an important illustration that learning to build peace education can be done through comic media. So we need a comic depiction that refers to Islam rahmatan lil 'alamin.

Building peace education in comic media, still limited to one comic, namely Iqomic Da'wah ala Komikus. Therefore, further studies related to this discussion are needed.

\section{ACKNOWLEDGMENTS}

I express my gratitude to the postgraduate for the publication fee and to the Research and Development Center for Literature and Religious Treasures of the Ministry of Religion for the opportunity to provide in Islage activities.

\section{REFERENCES}

[1] Z. Abidin and M. T. Ismail, "Pembangunan Pendidikan Perdamaian Dari Sekolah: Pendekatan Gerakan Sosial," Suhuf, 2019.

[2] W. Budiantoro, "Dakwah di Era Digital," KOMUNIKA J. Dakwah dan Komun., 2018, doi: 10.24090/komunika.v11i2.1369.

[3] E. D. Meinura, U. Supriadi, and M. I. Firmansyah, "PENGGUNAAN MEDIA KOMIK DALAM MOTIVASI BELAJAR SISWA ( PTK di Kelas XI TB 3 SMK Pariwisata Telkom Bandung Tahun Pelajaran 2018 / 2019 ) Oleh sebagai karenanya PAI juga instrument mengimplementasikan dalam tujuan Pendidikan itu sendiri . Sebagaimana Berdasa," vol. 1, no. 2, pp. 105-116, 2019.

[4] Y. A. Pratama, "Media Komik Dalam Pembelajaran Pendidikan Agama Islam Di Sdn 1 Sukabumi Bandar Lampung," J. MUDARRISUNA Media Kaji. Pendidik. Agama Islam, vol. 8, no. 2, p. 347, 2018, doi: $10.22373 / \mathrm{jm} . \mathrm{v} 8 \mathrm{i} 2.4123$.

[5] S. U. Faza Adilah, A. Ridwan, and D. Solahudin, "Komik Sebagai Media Dakwah," Tabligh J. Komun. dan Penyiaran Islam, vol. 4, no. 4, pp. 363-381, 2019, doi: 10.15575/tabligh.v4i4.1056.

[6] L. Mishra, T. Gupta, and A. Shree, "Guiding principles and practices of peace education followed in secondary schools of mizoram," Int. J. Eval. Res. Educ., 2020, doi: 10.11591/ijere.v9i4.20738.

[7] V. Tinker, "Peace education as a post-conflict peacebuilding tool," All Azimuth, 2016, doi: 10.20991/allazimuth.167339.

[8] L. Fitriani, "Pendidikan Peace Building Di Pesantren: Sebuah Upaya Mencegah Radikalisasi," ULUL ALBAB J. Stud. Islam, vol. 16, no. 1, p. 117,2015 , doi: 10.18860/ua.v16i1.3011.

[9] S. Hymel and L. Darwich, "Building peace through education," J. Peace Educ., vol. 15, no. 3, pp. 345-357, 2018, doi: 10.1080/17400201.2018.1535475.

[10] N. Ahmad, "Keunggulan Metode Dakwah Melalui Media," J. Komun. Penyiaran Islam, 
vol. 4, no. 1, pp. 31-48, 2016, [Online]. Available: journal.stainkudus.ac.id.

[11] R. Romli, "Dakwah Islam Era Globalisasi," Ath Thariq J. Dakwah dan Komun., 2019, doi: 10.32332/ath_thariq.v3i1.1383.

[12] R. D. Estuningtyas, "Strategi Komunikasi dan Dakwah Pada Kalangan Milenial di Era Modernisasi," Muttaqien; Indones. J. Multidiciplinary Islam. Stud., vol. 2, no. 01, pp. 75-86, 2021, doi: 10.52593/mtq.02.1.05.

[13] U. Inayah, S. Anwar, and B. Bahrudin, "Representasi Dakwah dalam Komik," Tabligh J. Komun. dan Penyiaran Islam, vol. 3, no. 1, pp. 76-96, 2020, doi: 10.15575/tabligh.v3i1.576.
[14] U. Jasad, "Da'wah Melalui Media Cetak," Mimb. Kesejaht. Sos., 2019.

[15] A. Saputra and R. Azka, "Pengembangan Komik Matematika untuk Memfasilitasi Kemampuan Pemahaman Konsep dan Motivasi Belajar Siswa SMP," J. Pengemb. Pembelajaran Mat., 2020, doi: 10.14421/jppm.2020.022-06.

[16] S. Zainal, S. Yunus, and F. A. Jalil, "Direct integration of peace education and its effects on students' understanding of peace," Talent Dev. Excell., 2020. 